\title{
Building Prevention to Protect: The Inter-American Human Rights System
}

Fecha de recepción: 17 de febrero de 2016

Fecha de aceptación: 11 de octubre de 2016

Doi: 10.12804/revistas.urosario.edu.co/acdi/a.5300

\section{Carlos Portales* and Diego Rodriguez-Pinzon $^{* *}$}

Abstract: The article explores the way that the Inter-American human rights system assumes the "responsibility to protect" in the context of serious violations of human rights that can be characterized as war crimes, crimes against humanity, genocide, and ethnic cleansing. The essay describes

* Carlos Portales is Professor and Senior Researcher at the Latin American Faculty of Social Sciences (FLACSO-Chile) in Santiago. He was Director of the Program on International Organizations, Law and Diplomacy at American University Washington College of Law. Previously, he was Ambassador of Chile to the UN Office in Geneva, to the Organization of American States, and to Mexico. He was Vice-President of the UN Human Rights Council (2009-2010). Email: carlos_portales@hotmail.com.

** Co-Director, Academy on Human Rights and Humanitarian Law and Co-Director of the Masters in International Human Rights and Humanitarian Law at American University's Washington College of Law. Washington D.C., United States. drodrig@wcl.american.edu Diego Rodriguez-Pinzon is Professorial Lecturer in Residence at American University Washington College of Law and Co-Director of the Academy on Human Rights and Humanitarian Law and the LLM in International Human Rights and Humanitarian Law in that institution. He served as Ad Hoc Judge in the Inter-American Court of Human Rights of the Organization of American States (OAS) from 2007 to 2011. He was also staff attorney at the Inter-American Commission on Human Rights of the OAS and has litigated several cases before international mechanisms on issues related to impunity, rule of law and human rights.

Para citar este artículo: Portales, C. \& Rodriguez-Pinzon, D., "Building prevention in order to protect: the Inter-American Human Rights System", Anuario Colombiano de Derecho Internacional (ACDI), 2017, 10, pp. 261-294. Doi: 10.12804/revistas.urosario.edu.co/acdi/a.5300 
how the Inter-American Commission on Human Rights and the InterAmerican Court of Human Rights have responded to such situations by using the ample powers granted to them by the OAS member states. The authors consider that these organs have been some of the most effective tools with which this region has confronted such situations by seeking to prevent them from occurring in the first place. The Inter-American system has contributed to building democratic regimes in the majority of the countries of the hemisphere. This has been crucial to avoiding serious violations of human rights such as those mentioned above, which would have required urgent international intervention to overcome.

Key words: Responsibility to protect; Inter-American Human Rights System; American Convention on Human Rights; Inter-American Commission on Human Rights; Inter-American Court of Human Rights.

\section{Construyendo prevención para proteger: el Sistema Interamericano de Derechos Humanos}

Resumen: el presente artículo explora la forma como el Sistema Interamericano de Derechos Humanos responde a la responsabilidad de proteger a personas en el contexto de violaciones graves a los derechos humanos que pueden caracterizarse como crímenes de guerra, crímenes de lesa humanidad, genocidio y limpieza étnica. El texto desarrolla algunos ejemplos sobre la forma como la Comisión Interamericana de Derechos Humanos y la Corte Interamericana de Derechos Humanos han respondido frente a dichas situaciones recurriendo a la diversidad de potestades que les han sido reconocidas a estos mecanismos de supervisión regional. Los autores sugieren que esta ha sido una de las formas más eficaces a través de las cuales los Estados del hemisferio americano han confrontado este tipo de situaciones y, más importante aún, han prevenido dichas violaciones. El Sistema Interamericano ha contribuido a sentar unas bases institucionales democráticas en la mayoría de los países del hemisferio, lo cual ha sido definitivo para evitar situaciones de graves violaciones de derechos humanos como las antes enunciadas, que habrían requerido la intervención internacional urgente para superar tales crisis.

Palabras clave: responsabilidad de proteger, Sistema Interamericano de Derechos Humanos, Convención Americana sobre Derechos Humanos, 
Comisión Interamericana de Derechos Humanos, Corte Interamericana de Derechos Humanos.

\section{Construindo prevenção para proteger: o Sistema Interamericano de Direitos Humanos}

Resumo: O presente artigo explora a forma como o Sistema Interamericano de Direitos Humanos responde à responsabilidade de proteger a pessoas no contexto de violações graves aos direitos humanos que podem caracterizar-se como crimes de guerra, crimes de lesa-humanidade, genocídio e limpeza étnica. O texto desenvolve alguns exemplos sobre a forma como a Comissão Interamericana de Direitos Humanos e a Corte Interamericana de Direitos Humanos têm respondido frente a ditas situações recorrendo à diversidade de potestades que lhes têm sido reconhecidas a estes mecanismos de supervisão regional. Os autores sugerem que esta tem sido uma das formas mais eficazes através das quais os Estados do hemisfério americano têm confrontado este tipo de situações e, mais importante ainda, têm prevenido ditas violações. O Sistema Interamericano tem contribuído a estabelecer umas bases institucionais democráticas na maioria dos países do hemisfério, o qual tem sido definitivo para evitar situações de graves violações de direitos humanos como as antes enunciadas, que haveriam requerido a intervenção internacional urgente para superar tais crises.

Palavras-chave: Responsabilidade de proteger, Sistema Interamericano de Direitos Humanos, Convenção Americana sobre Direitos Humanos, Comissão Interamericana de Direitos Humanos, Corte Interamericana de Direitos Humanos.

\section{Introduction}

To conduct a comprehensive analysis of the Responsibility to Protect (RTOP) in Latin America, it is necessary to consider how regional institutions have taken into account the prevention of genocide, war crimes, ethnic cleansing, and crimes against humanity, as well as capacity building to address them 
and collective action against them. ${ }^{1}$ We have to focus our study within the framework of the relationship between the principle of non-intervention in the external and internal affairs of sovereign states, historically claimed by Latin American countries in their relationships with the United States of America, and the protection of human rights embedded in democratic ideals claimed, but not necessarily practiced, in the region.

International recognition of the principle of responsibility to protect has been developed in the context of the transformation of the international community from a world of states with absolute sovereignty to a system of sovereign states with responsibilities to those whom they rule and to other sovereigns. ${ }^{2}$ The genocide in Rwanda in 1994 and massacres in Srebrenica in 1995 shocked the international community and raise the issue of protection when the authorities of the State are unable or unwilling to exercise their duties. Ethnic cleansing in Kosovo led the UN Secretary General of the United Nations to argue in 1999 for "humanitarian intervention" to protect lives of innocent civilians. The subsequent exchange of ideas and debates led the General Assembly to adopt the concept of Responsibility to Protect. ${ }^{3}$

On October 24, 2005, the United Nations General Assembly adopted resolution 60/1 2004, World Summit Outcome, including three paragraphs on the responsibility to protect all populations from genocide, war crimes, ethnic cleansing, and crimes against humanity. In paragraph 138, the GA declared that "each individual State has the responsibility to protect its population" from these four crimes, which "entails the prevention of such crimes, including their incitement, through appropriate and necessary means $[\ldots]$ ". ${ }^{4}$ The GA indicated that " $[t]$ he international community should, as appropriate, encourage and help States to exercise this responsibility and support the United Nations in establishing an early

1 Muñoz, H., La responsabilidad de proteger: tres pilares y cuatro crímenes, 10 Foreign Aff. Latinoamérica at 101, 101 (2010).

2 Lyons, G. M. \& Mastanduno, M. (Eds.), Beyond Westphalia? State Sovereignty and International Intervention (1995).

3 See Rep. of the Sec'y Gen.'s High-level Panel on Threats, Challenges and Change, A more secure world: our shared responsibility, un Doc. A/59/565 (2004); un Secretary General, In Larger Freedom: Towards Security, Development and Human Rights for All, UN Doc. A/59/2005 (March 21, 2005).

4 G.A. Res. 60/1, ๆ 138 (Oct. 24, 2005). 
warning capacity". 5 In addition, in paragraph 139 , the GA added that " [ $\mathrm{t}$. international community, through the United Nations, also has the responsibility to use appropriate diplomatic, humanitarian, and other peaceful means" to help protect populations from these heinous crimes, and indicated that it is prepared to take collective action through the Security Council "on a case-by-case basis and in cooperation with relevant international organizations as appropriate, should peaceful means be inadequate and national authorities are manifestly failing to protect their populations from genocide, war crimes, ethnic cleansing, and crimes against humanity". 6

Human rights have been a core element in regional collaboration in the Americas over the last 70 years. ${ }^{7}$ Regional concern for the protection of human rights emerged in the Inter-American Conferences at the beginning of the twentieth century, but the consecration of the principle of non-intervention was the main banner of Latin American states in that period, and regional human rights enforcement raised the specter of intervention. At the Inter-American Conference on Problems of War and Peace in 1945, The American states agreed that "[i]nternational protection of essential rights of man would eliminate the misuse of diplomatic protection of citizens abroad, the exercise of which has more than once led to the violation of the principles of non-intervention and of equality between nationals and aliens, with respect to the essential rights of man". 8 Thus, regional protection of human rights should contribute to avoid unilateral intervention.

In this article we will discuss the role that the Inter-American human rights system has played in enhancing the preventive dimension of the Responsibility to Protect. We seek to show how the collective action of American states through its main international human rights institutions, the Inter-American Commission on Human Rights (hereinafter IACHR or the "Commission") and the Inter-American Court of Human Rights (hereinafter the IACTHR or the "Court"), has served the purpose of creating a hemispheric environment in which gross and systematic violations of

\footnotetext{
$5 \quad$ Id. $\ 139$.

$6 \quad$ Id. $\ 139$.

7 Goldman, R., History and Action: The Inter-American Human Rights System and the Role of the Inter-American Commission on Human Rights, 31 Hum. Rts. Q. 856 (2009).

8 Inter-American Conference on Problems of War and Peace, Report of the Delegation of the United States of America, Resolution XL on the International Protection of the Essential Rights of Man, 108 (1946) quoted in id. at 858.
} 
human rights or war crimes are no longer possible. ${ }^{9}$ We will present examples of how these organs have gone beyond the traditional role of human rights supervisory organs by expanding the impact of their resolutions and decisions to prevent future grave violations of human rights, not just repairing the rights of individual victims in specific cases. We will also present examples of the practice of these organs regarding amnesty laws and country situations where, arguably, crimes against humanity or war crimes were occurring. Moreover, we will discuss how the Commission and the Court have cautiously enhanced collective reparations in grave violations of human rights and developed a very robust system of interim measures to prevent human rights violations and call the attention of the States of the Americas to situations that could evolve into more serious violations. Overall, these examples will help illustrate the wide variety of tools used by the Commission and the Court and serve as a hemispheric "early warning system," the "preventive structure" of the Americas.

\section{The Historical Context in which the Inter-American System Evolved}

In analyzing the historical context in which the Inter-American system evolved, it is important to highlight the difficulties that accompanied the process. Although the Inter- American Conference of 1948 requested the drafting of a binding agreement on human rights, it took more than two decades to approve the 1969 Inter-American Convention.

On April 30, 1948, the ninth Inter-American Conference held in Bogotá adopted the Charter of the Organization of the American States,

\footnotetext{
9 The Inter-American Court has dealt with situations in which systematic violations were occurring since its first case - Velasquez Rodríguez v. Honduras, Merits, Judgment, InterAm. Ct. HR (ser. C) No. 4 (July 29, 1988)—. These serious violations or human rights can be characterized as crimes against humanity as defined subsequently by the international community in Articles 6, 7, and 8 of the Rome Statute of the International Criminal Court (opened for signature July 17, 1998, 2187 UNTS 90 (entered into force July 1, 2002)). Furthermore, the Inter-American Commission has dealt with war crimes in its own reports. For example, in the Third Report on Democracy and Human Rights in Colombia, the Commission dealt with violations to the applicable norms of International Humanitarian Law in the noninternational armed conflict in that country - Inter-Am. Commission on Human Rights, Third Report on Democracy and Human Rights in Colombia, OEA/Ser.L/V/II.102, doc. 9 rev. 1 (Feb. 26, 1999), http://www.cidh.org/countryrep/colom 99 en/table\%20of\%20 contents.htm (last accessed Oct. 5, 2016)—.
} 
recognizing the principle of non-intervention as a fundamental basis for the new regional regime (art. 19). On May 2, the Conference approved the American Declaration of the Rights and Duties of Man (hereinafter, the American Declaration), seven months before the adoption of the Universal Declaration of Human Rights by the United Nations General Assembly. The American Declaration considers human rights based upon attributes of the human personality. The Declaration affirms the right to the life, liberty, and security of the person (art. I), as well as equality before the law, without distinction as to race, sex, language, creed, or any other factor (art. II), establishing the basis for regional protection, and therefore affirming the essential element of prevention of the four crimes considered by RTOP. The American Declaration was not binding, but it progressively became today's regional legal system: the Inter-American Human Rights System.

In 1959, taking into consideration the external terrorist activities of the dictatorship in the Dominican Republic, the Meeting of Foreign Ministers decided to create an Inter-American Commission on Human Rights, whose statute was approved in 1960 with a consultative and advisory role. Nevertheless, the activities of the IACHR were soon expanded, making reports on human rights violations in Cuba, Guatemala, the Dominican Republic, Paraguay, and Nicaragua. The most important case was IACHR mission to the Dominican Republic in 1965 after the sending of the Inter-American Peace Force to that country.

Shortly thereafter, the Secretary General of the OAS asked the Commission to visit Santo Domingo to investigate numerous charges of human rights violations lodged by rival factions contending for power. From the time it arrived, the Commission played an active and important role in the peacekeeping operations. It helped to protect lives of innocent bystanders, negotiated mutual prisoner releases, and secured the release and safe-passage from the country of various political leaders. ${ }^{10}$

In 1966, the OAS expanded the IACHR's functions and powers, allowing it to examine communications submitted to it and other available information, to request pertinent information from any American state, and to make recommendations for more effective observance of

10 Goldman, R., supra note 8, at 870. 
fundamental rights. Furthermore, the OAS mandated the IACHR to submit an annual report to the Inter-American Conference or to the Meeting of Consultation of Foreign Ministers, including a statement of progress achieved in the realization of the goals set forth by the American Declaration; a statement of areas in which further steps are needed to give effect to human rights; and observations as the IACHR may deem appropriate on matters covered in communications submitted to it and in other information available to it. Furthermore, in 1967 the III Special Inter-American Conference in Buenos Aires made the Commission "a principal organ" of the Charter. ${ }^{11}$

In the following period, many Latin American countries were governed by military dictatorships under the "national security doctrine", which implemented policies that violated the most basic human rights. Under these regimes, for example, murder, torture, and disappearances were widely practiced, the proscription of political parties, labor unions, and student groups was systematic, and media censorship was common. Furthermore, human rights organizations and activists were considered subversive. For most of this period, the United States applied human rights policy through a Cold War prism, supporting counter-insurgency in Central America and being very weak in the Southern Cone. In that context, the Inter-American Commission played a significant role in reporting human rights violations in Chile, Paraguay, Uruguay, and Argentina, and started to pursue individual cases.

The development of individual cases in the IACHR, the effective functioning of the Court, and the submission of cases to the Court by the IACHR since 1986 have produced a more adequate system for dealing with human rights situations in the period after the end of most of the authoritarian governments in the region. Over the last twenty-five years, the Commission has continued monitoring countries with fragile democratic institutions that experience political violence, and the Court developed strong jurisprudence in cases that had gone well beyond the right to life and basic civil liberties, expanding the application of the rights enumerated in the American Convention on Human Rights. In recent years, however, many governments have contested the Inter-American organs

11 Goldman, R., supra note 8, at 867-871. 
and promoted the restriction of their powers, while some of them have denounced the American Convention. ${ }^{12}$

\section{Brief description of the Inter-American Human Rights System}

The Inter-American Human Rights system is comprised by several regional human rights treaties. In addition to the 1948 American Declaration, the OAS states adopted the American Convention on Human Rights (ACHR) in 1969, which entered into force in 1978. This instrument contains the main provisions that recognize the basic human rights that are to be the core subject of protection by state parties. The Declaration and the Convention constitute the core set of substantive human rights standards that govern the conduct of states in the Americas. However, the Convention has been complemented by several other regional instruments including the Inter-American Convention to Prevent and Punish Torture, the Inter-American Convention on Forced Disappearances of Persons, the Inter-American Convention on the Prevention, Punishment, and Eradication of Violence Against Women (Belém Do Pará), as well as the Additional Protocol to the ACLR on Economic, Social and Cultural Rights (Protocol of San Salvador), and the Protocol to the ACHR to Abolish the Death Penalty. Additionally, the system adopted the Inter-American Convention on the Elimination of All Forms of Discrimination Against Persons with Disabilities, with a different supervisory structure than that of the other conventions. Morevover, the Inter-American Convention Against All Forms of Discrimination and Intolerance and the Inter-American Convention Against Racism, Racial Discrimination, and Related Forms of Intolerance were recently adopted but have not yet entered into force.

It should be noted that the regional human rights instruments effectively recognized the principle that States were primarily responsible for protection of human rights in their jurisdictions. This responsibility had several dimensions. States were bound to "protect" human beings from violations of their rights, and had to "guarantee" or "ensure" such rights, which included the obligation to "prevent" such violations in the first place. This notion was reaffirmed when states adopted the IACHR Statute, which since 1965 required that any petitions filed before the Commission

12 Goldman, R., supra note 8, at 874-878. 
should first exhaust domestic remedies to grant the state concerned the opportunity to remedy a possible human rights violation before international mechanisms could be activated.

\section{Supervision}

One of the most significant developments in the evolution of the preventive character of the Inter-American Human Rights System is the creation of the Inter-American Commission and the Inter-American Court of Human Rights (hereinafter "Inter-American Court"). These organs have evolved significantly and currently have a broad array of powers that allow them to intervene when there are serious violations of human rights in any country of the Americas, many of which have been characterized by atrocities that rise to the level of crimes against humanity and war crimes.

\section{a) The Inter-American Commission on Human Rights}

Since it was established in 1960, the Inter-American Commission has had a mandate that allows it to supervise all OAS member states under the standards recognized in the American Declaration of 1948. This mandate now includes all North American states, Central American and Caribbean states, and South American States. This is particularly important regarding states that are not parties to the American Convention on Human Rights, such as the United States, Canada, Venezuela, and several Caribbean states. ${ }^{13}$

\section{b) The Inter-American Court of Human Rights}

The Inter-American Court plays a key role in the human rights supervisory machinery of the OAS. Being the only judicial body of the OAS, its judgments and decisions carry the legal authority that only such a body can convey. Therefore, although its judicial mandate limits the way in which it can engage with situations entailing serious human rights violations, it

\footnotetext{
13 What is the LACHR?, Inter-Am. Commission on Hum. Rts., http://www.oas.org/en/ iachr/ mandate/what.asp (last accessed Oct. 5, 2016). It should be mentioned that Venezuela ratified the American Convention on Human Rights in 1977, but denounced the instrument in 2012. Similarly, Trinidad and Tobago ratified the Convention in 1991, and denounced it in 1998.
} 
has been able to articulate its contentious and advisory jurisdictions to have significant impact in the states of the Americas.

Some examples of these mechanisms are its provisional measures and the reparations it orders in its contentious cases, both of which we will further explore below.

\section{Individual Cases}

Individual cases play a crucial role in the supervisory role of the InterAmerican System. They are possibly the single most important mechanism to induce states to exercise their primary "responsibility to protect" communities under their jurisdiction from gross and systematic violations to their most basic rights. Below we review some examples of the work of the Inter-American System in this role, which is complementary to national institutions.

\section{Amnesties}

One of the major contributions of the Inter-American System to confronting massive and systematic human rights violations has been its response to amnesty laws. Several authoritarian regimes of the Americas resorted to amnesty laws in order to avoid prosecution by emerging democratic governments for the gross violations perpetrated during their dictatorships. The Inter-American Commission and the Inter-American Court have developed international standards that severely restrict the validity of such laws where serious violations such as crimes against humanity or war crimes were committed.

After the dictatorship in Argentina, the new democratic government adopted the Ley de Obediencia Debida (Law of Due Obedience) and the Ley de Punto Final (Full Stop Law), which shielded from prosecution those military officials who had perpetrated crimes against humanity. ${ }^{14}$ In a crucial decision in 1992, the Inter-American Commission found that these laws were incompatible with the American Convention and the

14 See Brian D. Tittemore, Ending Impunity in the Americas: The Role of the Inter-American Human Rights System in Advancing Accountability for Serious Crimes Under International Law, 12 (2005-2006) Southwestern Journal of Law and Trade in the Americas 429, 450-455 (2006). 
American Declaration. ${ }^{15}$ In the same year, the IACHR also issued a similar decision outlawing the Uruguayan amnesty law known as the Ley de Caducidad (Caducity Law), ${ }^{16}$ which was adopted by the new democratic government and reaffirmed by a referendum adopted by a significant majority of Uruguayan voters. ${ }^{17}$ Similarly, in 1992 the IACHR also declared in Las Hojas Massacre v. El Salvador that El Salvador's Amnesty Law violated the American Convention. ${ }^{18}$ Subsequently, in 1996, the Commission reached the same conclusion regarding the Chilean amnesty adopted by the authoritarian regime of Augusto Pinochet. ${ }^{19}$

In 2001, the Inter-American Court issued a ruling on Barrios Altos v. Peru ${ }^{20}$ which was the tribunal's first decision regarding amnesties. This decision was followed in 2010 by the decision of the Inter-American Court in the Case of Gomes Lund et al (Guerrilha do Araguaia) against Brazil, ${ }^{21}$ for adopting and applying its Amnesty Law (Law No. 6.683/79) in violation of the American Convention. In 2011, the Court also issued a decision against

15 Herrera v. Argentina, Cases 10.147, 10.181, 10.240, 10.262, 10.309 and 10.311, InterAm. Commission H.R., Report No. 28/92, OEA/Ser.L/V/II.83, doc. 14 (1993).

16 Hugo Leonardo de los Santos Mendoza v. Uruguay, Cases 10.029, 10.036, 10.145, 10.305, 10.372, 10.373, 10.374 and 10.375, Inter-Am. Commission H.R., Report No. 29/92, OEA/ Ser.L/V/II.83, doc. 14 (1993).

17 The Commission indicated regarding the Caducity Law adopted by referendum that the "application of the Convention and examination of the legal effects of a legislative measure, either judicial or of any other nature, insofar as it has effects incompatible with the rights and guarantees embodied in the Convention or the American Declaration, are within the Commission's competence" (id. at 931 ).

18 See Las Hojas Massacre v. El Salvador, Case 10.147, Inter-Am. Commission H.R., Report No. 26/92, OEA/Ser.L/V/II.83, doc. 14 (1993) (holding that the Commission would follow the same approach in subsequent cases and indicating that El Salvador should "render null and void the General Amnesty Law"). See also Ignacio Ellacuria, S.J. et. al. v. El Salvador, Case 10.488, Inter-Am. Commission H.R., Report No. 136/99, OEA/Ser.L/V/II.106, doc. 6 (1999); Monsenor Oscar Romero v. El Salvador, Case 11.481, Inter-Am. Commission H.R., Report No. 37/00, OEA/Ser.L/V/II.106, doc. 3 rev. 971 (1999).

19 Héctor Marcial Garay Hermosilla v. Chile, Case 10.843, Inter-Am. Commission H.R., Report No. 36/96, OEA/Ser.L/V/II.95 Doc. 7 rev. 156 (1997).

20 Barrios Altos v. Peru, Merits, Judgment, Inter-Am. Ct. HR (ser. C) No. 75 (March 16, 2001).

21 Gomes Lund et al. ("Guerrilha do Araguaia") v. Brazil, Preliminary Objections, Merits, Reparations and Costs, Judgment, Inter-Am. Ct. HR (ser. C) No. 219 (Nov. 24, 2010). 
the amnesty law of Uruguay and in 2013 it rendered its judgment in the Case of the Massacres of El Mozote and nearby places in El Salvador. ${ }^{22}$

The decisions of the Commission and the Court regarding amnesty laws in the Americas had the important effect of empowering victims in their struggle for justice. ${ }^{23}$ Beyond this crucial outcome is the impact these decisions had on preventing, or at least limiting, future amnesties for gross violations of human rights. One clear example is the current situation in Colombia, where local actors appear to implicitly and explicitly acknowledge that blanket amnesty measures will not be possible in this country as a result of the peace process. In recent years, for example, Colombian legislators crafted a demobilization law for paramilitary groups (Ley de Justicia y Paz) that has characteristics similar to a plea bargain structure used in other states around the world to confront organized criminal organizations and convict perpetrators. ${ }^{24}$ The current Santos administration is now involved in a peace process with FARC guerrilla forces and this is one of the key issues being discussed in these negotiations.

The severe limitations on amnesty laws derived from the Commission and Court decisions have become a strong deterrent against heinous crimes in the region by strengthening the governments' obligation to protect. These decisions have created strong and consistent standards that states are compelled to abide by. This has additional importance in a hemisphere where constitutional systems are becoming more permeable to international law, which increasingly allows judicial systems to enforce the obligation to comply with international standards.

22 Gelman v. Uruguay, Merits and Reparations, Judgment, Inter-Am. Ct. HR (ser. C) No. 221 (Feb. 24, 2011). Massacres of El Mozote and nearby places v. El Salvador, Interpretation of the Judgment on Merits, Reparations and Costs, Inter-Am. Ct. HR (ser. C) No. 264 (Aug. 19, 2013).

23 For a more detailed analysis of this subject see Rodriguez-Pinzon, D., The InterAmerican Human Rights System and Transitional Processes, in Transitional Jurisprudence and the European Convention on Human Rights: Justice, Politics and Rights 239 (Antoine Buyse \& Michael Hamilton Eds., 2011).

24 Paramilitaries' Heirs: The New Face of Violence in Colombia, Human Rights Watch (Feb. 3, 2010), www.hrw.org/node/88060 (last accessed Oct. 5, 2016) (the implementation of the law has been subject to criticism from many observers as its effects appear to be very similar to those of an impunity or amnesty law. Petitions have been filed claiming that the law's adoption and implementation violates the Convention, but the Inter-American Court has so far declined to issue judgment on this matter). See also Rochela Massacre v. Colombia, Merits, Reparations and Costs, Judgment, Inter-Am. Ct. HR (ser. C) No. 163, ๆ 190-198 (May 11, 2007). 


\section{Reparations in Individual Cases: The Colombian Situation}

The case of Colombia provides some insight on how the Inter-American human rights bodies coordinate their work regarding reparations in individual cases related to gross and systematic human rights violations in the context of non-international armed conflict. Crafting adequate reparations for gross and systematic violations can be a particularly difficult task in contemporary international law. The Inter-American System can provide some lessons on how concerted action by international mechanisms can contribute to increase the pressure on states seeking to prevent future violations.

The experience of the Commission and the Court regarding Colombian "massacre cases" appears to suggest that there is a correlation between the first Colombian cases in the Commission's proceedings in the 1990s and the judgments of the Inter-American Court regarding Colombia a decade later. The Commission's cases may have allowed the Court to explore the measures ${ }^{25}$ and remedies the Colombian government was able or willing

25 "In the decade of the 1990s, under the Commission's auspices, very significant events occurred in the context of several friendly settlement discussions in cases of massacres perpetrated by Colombian state agents. The most notable cases, Massacre Los Uvos' v. Colombia, Caloto Massacre v. Colombia, (Caloto Massacre v. Colombia, 13 April 2000, IACHR, no. 36/00, Case 11.101, LACHR Annual Reports 1999) and Villatina Massacre v. Colombia (Villatina Massacre v. Colombia, 27 October 2005, IACHR, Friendly Settlement, no. 105/05, Case 11.141, LACHR Annual Reports 2005), were all being processed in the individual complaint system of the Commission. In a hearing held in 1995, the government agreed to initiate friendly settlement discussions for those events. (The friendly settlement in the Villatina Massacre case was successful, but it eventually failed in the Los Uvos Massacre case because of a lack of full compliance with the agreement-particularly regarding the prosecution of those responsible). The government indicated its willingness to adopt several types of reparations seeking to remedy these egregious violations of human rights. As part of those agreements, on July 29, 1998, Colombia's President Ernesto Samper publicly stated that government forces were internationally responsible under the American Convention for the violations committed in the massacres of Los Uvos, Caloto, and Villatina. This landmark event had structural importance in Colombia with extensive political and social repercussions. One of the most significant effects, among other very important outcomes, was the validation of human rights norms as a legitimate issue and a positive force within the Colombian conflict. The fact that Colombia's President came out publicly and stated that the actions by the security forces of Colombia were a violation of basic human rights of the victims, as recognized by international law, significantly empowered an important constituency of human rights defenders and victims". (Rodriguez-Pinzon, D., Selected Examples of 
to subsequently "accept" and comply with. The Colombian government agreed to several types of reparatory measures. These included, among others, compensating the victims, establishing symbolic reparations, as well as "formulating or implementing, as appropriate, the pending social compensation projects for attending to the displaced families and individuals, health, education, electric power, the Piedra Sentada-Los Uvos road, and job creation". ${ }^{26}$ All these reparatory measures were developed in the context of international and national negotiations between victims' representatives and the state in cases pending before the Commission.

Later, the Inter-American Court received the Commission's applications in several other massacre cases against Colombia: ${ }^{27}$ Case of the Mapiripán Massacre v. Colombia, ${ }^{28}$ Case of the 19 Tradesmen v. Colombia, ${ }^{29}$ Case of the Pueblo Bello Massacre v. Colombia, ${ }^{30}$ Case of the Ituango Massacres v. Colombia, ${ }^{31}$ and Case of the Rochela Massacre v. Colombia. ${ }^{32}$ The reparations later ordered in those cases by the Court appear to resemble those provided by the Commission in the earlier Colombian massacre cases. The reparations granted by the Court in those cases included monetary compensation and the reaffirmation of the duty to investigate, prosecute, and

the Contemporary Practice of the Inter-American System in Confronting Grave Violations of Human Rights: United States and Colombia, in Making Peoples Heard: Essays on Human Rights in Honour of Gudmundur Alfredsson 371, 383-384 (Asbjorn Eide et al. Eds., 2011).

26 Inter-Am. Commission on Human Rights, Report of the Coordinating Committee for Following Up on the Recommendations of the Comité de Impulso for the Incidents of Los Uvos, Caloto, and Villatina, quoted in Massacre "Los Uvos" v. Colombia, Case 11.020, Inter-Am. Commission HR, Report No. 35/00, OEA/Ser.L/V/II.106, doc. 3 rev. $\ 24$ (1999).

27 Las Palmeras v. Colombia, Merits, Judgment, Inter-Am. Ct. HR (ser. C) No. 90 (Dec. 6, 2001) (the first massacre case filed before the Court against Colombia). However, this case had very tentative results in many legal questions and reparations, which were not followed by the Court in its subsequent practice.

28 Mapiripán Massacre v. Colombia, Preliminary Objections, Inter-Am. Ct. H.R. (ser. C) No. 122 (March 17, 2005).

29 19 Tradesmen v. Colombia, Merits, Reparations and Costs, Judgment, Inter-Am. Ct. HR (ser. C) No. 109 (July 5, 2004).

30 Pueblo Bello Massacre v. Colombia, Interpretation of the Judgment, Inter-Am. Ct. HR (ser. C) No. 159 (Nov. 25, 2006).

31 Ituango Massacres v. Colombia, Preliminary Objection, Merits, Reparations and Costs, Judgment, Inter-Am. Ct. HR (ser. C) No. 148 (July 1, 2006).

32 Rochela Massacre v. Colombia, supra note 25. 
punish perpetrators of gross and systematic violations of human rights. One important characteristic of the Inter-American System is that it is specially oriented to confront impunity for serious violations. The Court consistently orders States to prosecute and punish those responsible for massacres and other crimes against humanity and/or war crimes along with establishing that amnesties for such crimes are incompatible with the American Convention. ${ }^{33}$ Additionally, the Court has declared that domestic legislation, such as amnesties or a statute of limitations, cannot present obstacles to the prosecution of the perpetrators of serious human rights violations.

The Commission and the Courts' considerations of individual cases and reparations ordered by these organs have also strengthened the obligation to protect well beyond the specific effects of the individual decisions for the parties. These decisions create public awareness about the need for robust state action in each jurisdiction to protect the population against serious crimes. Furthermore, individual cases, mainly those of the Inter-American Court, are considered by many national tribunals of the Americas as authoritative sources of interpretation of the American Convention and, therefore, have a de facto erga omnes effect that amplifies decisions and strengthens their effects in inducing national action in several states based on a decision in a single individual case.

\section{Prevention: Precautionary Measures and Provisional Measures}

The practice of the Inter-American System in the adoption of interim measures has been a very important aspect of its work seeking to 'prevent' serious human rights violations. This is especially important if we consider that the Americas is a region where gross and systematic violations of human rights involving extra-judicial killings, torture, and forced disappearances were prevalent. Since its creation in 1948, the OAS has adopted multiple treaties that recognize implicitly or explicitly the power of the

33 Barrios Altos v. Peru, supra note 21 (the Court declared that the Peruvian amnesty violated the American Convention and was null and void); also, in the Mapiripán Massacre case (supra note 29), the Court stated that amnesties or any other obstacle to investigate and prosecute this type of serious human rights violations would be incompatible with the Convention. 
Commission and the Court to issue protective measures to adequately protect the basic rights recognized in their provisions.

The Commission issued more than 780 precautionary measures between 1995 and 2012, mostly focusing on the core basic rights recognized by human rights instruments. A recent study has shown that the Commission has adopted a great majority of its measures in cases where life and personal integrity were at stake. ${ }^{34}$ According to this study, measures adopted from 1996 to 2010 were issued to protect "the right to life (article 4) with 599 measures and the right to humane treatment (article 5) with 528 measures from a total of 688)". ${ }^{35}$ Clearly, precautionary measures have primarily been used in serious situations where the most basic rights of persons were at stake.

The Inter-American Court, for its part, has issued more than 526 orders in provisional measures since it was established 1980. Similarly to the Commission, the great majority of these measures are related to the right to life and personal integrity. They are firmly grounded in the American Convention, Art. 63.2, which expressely recognizes this power of the Court. Furthermore, Art. 68.1 of the Convention indicates that the decisions of the Court are legally binding, which evidently includes provisional measures. This solid legal structure reinforces the power of these interim measures of the Court and also strengthens the authority of precautionary measures ${ }^{36}$ of the Commission regarding those States that are parties to the American Convention.

Interim measures have been concrete instruments to exert pressure on governments to exercise protection in risky situations in real time. They immediately trigger the "responsibility to protect" in specific situations, usually connected to the existance of an armed conflict or a systematic

\footnotetext{
34 Burbano-Herrera, C. \& Rodriguez-Pinzon, D., Precautionary Measures Issued by the Inter-American Commission on Human Rights, in Preventing Violations of Human Rights: Are Urgent, Interim or Provisional Measures an Adequate Tool in Human Rights Litigation? (Yves Haeck \& Clara Burbano-Herrera Eds., 2015).

35 Id. at 5.

36 The question of the legal status of precautionary measures requested by the Commission has been often raised by some states, but the nature of this organ as well as the overall nature of the Inter-American system has largely settled this discussion in recognizing such authority under the main human rights instruments of the OAS (Rodriguez-Pinzon, D., Precautionary Measures of the Inter-American Commission on Human Rights: Legal Status and Importance 20 Hum. Rts. Brief, 2013, at 13).
} 
violation of basic human rights. These measures are one of the most important mechanisms that the Inter-American System has to react to situations that are ocurring.

\section{The U.S. and Guantanamo}

One interesting example of the practice of the Inter-American System regarding interim measures is how the Inter-American Commission responded to allegations of systematic violations which occurred after $9 / 11$. The IACHR is one of the only international organs that has jurisdiction to receive communications for human rights violations against the United States as a member state of the OAS. Based on this authority, the Commission issued orders in one of the most controversial issues surrounding the detainees brought by the U.S. to Guantanamo Bay after 9/11.

On March 12, 2002, the IACHR issued the first precautionary measures regarding Guantanamo detainees, which exemplified the Commission's methods in confronting abusive official reactions in the so-called "War on Terrorism". ${ }^{37}$ The precautionary measures focused on the need to have a competent tribunal to determine the legal status of the detainees and to provide the detainees with the legal mechanisms that they were entitled to. Moreover, the IACHR specifically indicated that the United States was responsible for ensuring the rights of the detainees, because although the Guantanamo naval base is not located on U.S. territory, these individuals are clearly under the authority and control of U.S. authorities. ${ }^{38}$ In response to the first precautionary measure, the United States argued that the Commission lacked jurisdiction to apply norms of international humanitarian law or to issue precautionary measures against OAS members that had not ratified the American Convention. ${ }^{39}$ The IACHR rejected these objections, reaffirmed the measures, and reiterated its request for information, demonstrating its doubts about the legal status and rights of Guantanamo detainees captured in Bosnia and Pakistan. ${ }^{40}$

37 Rodriguez-Pinzon, D. \& Martin, C., The Inter-American Human Rights System: Selected Examples of its Supervisory Work, in Research Handbook on International Human Rights Law (Sarah Joseph A. McBeth eds, 2010) p. 362.

$38 \quad$ Id.

39 Inter-Am. Commission on Human Rights, Precautionary Measures 2002, ๆ 80, www. cidh.org/medidas/2002.eng.htm (last accessed Oct. 5, 2016).

$40 \quad I d$. 
In 2003 and 2004, the IACHR continued to express serious concern with the reports of mistreatment and methods of abuse that detainees were subjected to. The Commission requested that the State provide information about the status and treatment of detained persons in any detention center under the control of the United States, along with providing further information on detainees under the age of eighteen. The IACHR also requested that the State adopt all necessary measures to conduct independent, impartial, and effective investigations of the allegations of torture, taking into account that the investigations must examine the actions of perpetrators, and any mandated orders from superiors. ${ }^{41}$ The U.S. Government responded to the IACHR, claiming again that the Commission lacked jurisdiction to issue precautionary measures against the U.S and that because recourse to domestic policies was not exhausted, the IACHR was not competent to hear the case. ${ }^{42}$

On October 28, 2005, the Commission requested the United States to guarantee that the detainees in Guantanamo would not be transferred to countries where they would be in danger of torture or other mistreatment, ${ }^{43}$ that the use of statements given under torture be disallowed in legal proceedings, ${ }^{44}$ that the investigations not be conducted by the Department of Defense, and that the tribunal be competent to establish the legal status of the detainees and provide them with basic legal rights. ${ }^{45}$ In July 2006, U.S. non-compliance with the previous precautionary measures compelled the IACHR to urge the U.S. to close Guantanamo; to remove the detainees in a manner consistent with international human rights and international humanitarian law; to comply with the obligation of nonrefoulement, and to investigate, prosecute, and punish any acts of torture or other cruel, inhuman, or degrading treatment. ${ }^{46}$

\footnotetext{
41 Inter-Am. Commission on Human Rights, Pertinent Parts of July 29, 2004 Reiteration and Further Amplification of Precautionary Measures (Detainees in Guantanamo Bay, Cuba), 45 ILM 671, 672 (2006).

42 Tittemore, B., supra note 15, at 395-396.

43 Id. at 678 .

${ }^{44} \quad$ Id.

$45 \quad I d$.

46 Inter-Am. Commission on Human Rights, Res. No. 2/06, On Guantanamo Bay Precautionary Measures (July 28, 2006), https://www.cidh.oas.org/annualrep/2006eng/ ANNEXES/Annex\%205eng.htm (last accessed Oct. 5, 2016).
} 
On March 21, 2006, the Commission issued precautionary measures in favor of Omar Khadar, a nineteen-year-old Canadian detainee in Guantanamo. The IACHR requested that the U.S. adopt all measures necessary to prevent the use of torture and mistreatment, investigate and bring to justice any individuals responsible for such acts, and ensure that statements obtained by torture would not be used as evidence. ${ }^{47} \mathrm{Si}$ milarly, on August 20, 2008, the IACHR granted precautionary measures for Mr. Djamel Ameziane, who was also detained in Guantanamo. The Commission requested that the United States take necessary measures "to ensure that Mr. Ameziane is not subject to torture or to cruel, inhumane or degrading treatment and to make certain that he is not deported to any country where he might be subjected to torture or other mistreatment". ${ }^{48}$

In 2007, the Commission sought permission to conduct a visit to the Guantanamo Bay Naval Base to monitor conditions of detention. The U.S. Government granted permission with the condition that the delegation would not be able to interview detainees. The IACHR declined to carry out the visit with this limitation. ${ }^{49}$ After President Obama announced his intention to close the detention center at Guantanamo Bay, the Commission issued a press release on January 27, 2009, stating “its deep satisfaction over the decision by the President of the United States, Barack Obama, to close the detention center at the Guantanamo Bay Naval Base within a period of no later than one year and to prohibit cruel, inhuman, or degrading treatment in interrogations of detained individuals". ${ }^{50}$

In 2011, the IACHR issued Resolution No. 2/11 Regarding the Situation of the Detainees at Guantanamo Bay, asserting that the detention of the individuals at Guantanamo constitutes a violation of fundamental rights. ${ }^{51}$

47 Inter-Am. Commission on Human Rights, Annual Report of the IACHR 2006, Chapter III, ๆ 44, www.cidh.org/ annualrep/2006eng/Chap.3c.htm (last accessed Oct. 5, 2016).

48 Inter-Am. Commission on Human Rights, IACHR Annual Report 2008, Chapter III The Petition and Case System (Continuation), \ 37, www.cidh.org/annualrep/2008eng/ Chap3.e.eng.htm (last accessed Oct. 5, 2016).

49 Inter-Am. Commission on Human Rights, Address by the Chairman of the InterAmerican Commission on Human Rights, Paolo Carozza (April 3, 2008), http://www. cidh.org/Discursos/04.03.08eng.htm (last accessed Oct. 5, 2016).

50 LACHR Welcomes Order to Close Guantanamo Detention Center, Inter-Am. Commission on Human Rights (Jan. 27, 2009), www.cidh.oas.org/Comunicados/English/2009/02-09eng. htm (last accessed Oct. 5, 2016).

51 Inter-Am. Commission on Human Rights, Res. No. 2/11 Regarding the Situation of 
The Commission again urged the U.S. to close Guantanamo and try the detainees pursuant to international human rights and humanitarian law. ${ }^{52}$

\section{Country reports and in loco visits}

General and special reports of the Inter-American Commission have been one of the most notable aspects of the Commission's work regarding grave violations of human rights. Since its creation, the IACHR has interpreted its Statute as allowing it to issue Reports to be able to cooperate with states seeking to improve their human rights situation. Some of the more significant reports have been the result of previous on-site visits of the Commission to a state. In this complex process the IACHR is able to engage with different sectors of society during its in loco visits and gather the information necessary to subsequently report to the international community about the human rights situation in a particular country. The appropriate use of these mechanisms allows the IACHR to "intervene" in a specific situation, not by virtue of forceful actions by the international community, but due to its recognized human rights authority and the power of its presence and statements. This body is able to engage, in real time, with a domestic situation that appears to be escalating. It can request an immediate visit to a country and/or it can decide to release a report in its Annual Report or a more comprehensive Special Report. In this way, the IACHR can inject itself and communicate with local actors who use the report of the Commission in their local advocacy efforts.

Furthermore, the IACHR presents these reports, as well as its Annual Report, to the General Assembly of the OAS every year. The purpose of these reports is to call to the attention of the political bodies of the OAS serious situations where the regional international community could require collective action.

These reports have been examples of how the Commission has used its power to prevent gross and systematic violations of human rights. Below we will describe some of the preventive actions adopted by the IACHR, based on the finding of facts and recommendations in its reports on

the Detainees at Guantanamo Bay, United States, MC 259-02 (July 22, 2011), http:/ /www. cidh.oas.org/pdf\%20files/Resolution\%202-11\%20Guantanamo.pdf

$52 \quad$ Id. 
the human rights situation in Argentina (1980), ${ }^{53}$ Peru (2000), ${ }^{54}$ Colombia (1999), ${ }^{55}$ and the thematic report on terrorism (2002). ${ }^{56}$

\section{Report on the Situation of Human Rights in Argentina - 1980}

In the 1990s the Inter-American Commission closely monitored the situation of human rights in Argentina. The IACHR carried out an on-site visit in 1979 and issued a Special Report in 1980. The on-site visit mainly consisted of interviews with public officials, including several former Presidents of Argentina, major religious figures, representatives of political organizations, professional associations, trade unions and workers' organizations, and commercial, industrial, and business entities, to discuss the status of human rights in Argentina. ${ }^{57}$ The Commission also visited several prisons to conduct investigative work, where it received individuals and groups interested in stating problems or filing denunciations about human rights violations, including relatives of the disappeared and other victims of the regime.

The report, which was largely based on its findings during the on-site visit, discussed the political turmoil caused by the establishment of the de facto regime in Argentina to explain the context of clandestine detention and forced disappearances that occurred in the country. Before the in loco visit to investigate the human rights situation in Argentina, the IACHR had received a large number of claims affecting a considerable number of people in Argentina, and chose to discuss a selection of representative case histories of disappearances in its report. Victims' accounts of such

53 See Inter-Am. Commission on Human Rights, Report on the Situation of Human Rights in Argentina, OEA/Ser.L/V/II.49, doc. 19 corr.1 (April 11, 1980), http://www. cidh.org/countryrep/Argentina80eng/toc.htm (last accessed Oct. 5, 2016).

54 See Inter-Am. Commission on Human Rights, Second Report on the Situation of Human Rights in Peru, OEA/Ser.L/V/II.106, doc. 59 rev. (June 2, 2000), http://www. cidh.org/countryrep/Peru2000en/TOC.htm (last accessed Oct. 5, 2016).

55 See Inter-Am. Commission on Human Rights, supra note 10.

56 See Inter-Am. Commission on Human Rights, Report on Terrorism and Human Rights, OEA/Ser.L/V/II.116, doc. 5 rev. 1 corr. (Oct. 22, 2002), http://www.cidh.org/Terrorism/ Eng/toc.htm (last accessed Oct. 5, 2016).

57 See Inter-Am. Commission on Human Rights, Report on the Situation of Human Rights in Argentina, OEA/Ser.L/V/II.49, doc. 19 corr.1 || B.3 (April 11, 1980), http:// www.cidh.org/countryrep/Argentina80eng/ introduction.htm (last accessed Oct. 5, 2016). 
violations suggested the existence of a systematic pattern of violations perpetrated by state agents. ${ }^{58}$

The Commission requested that the State adopt several measures to prevent additional human rights violations. It urged the State to investigate, bring to trial, and punish the state agents who were perpetrators, conduct an in-depth investigation into denunciations concerning the use of torture and other forms of coercion, and punish those responsible for such acts. ${ }^{59}$ The State was encouraged to train officials and agents responsible for the maintenance of public order and state security on the respect for the rights of detainees. ${ }^{60}$ The Commission called upon the State to provide humanitarian treatment to those detained for reasons of security or public order and to ensure due process guarantees and legal defense during legal proceedings. ${ }^{61}$ The Commission called upon the State to ensure the right of trade union association, the rights of workers' organizations, political rights, the right to freedom of religion, and to worship. ${ }^{62}$ Lastly, the Commission requested that the State create a file centralizing information about inmates from the time of their detention to their transfer to prison, identifying exactly who had performed these operations for the purpose of consultation by the public and by the families of detainees. ${ }^{63}$

\section{Second Report on the Situation on Human Rights in Peru - 2000}

The relationship between the government of Peru and the IACHR was difficult. The Fujimori government refused to cooperate with the Commission, while stating its intention to restore democracy. The introduction of antiterrorism legislation resulted in many complaints to the IACHR because certain provisions of the legislation violated human rights, such as the right

58 See Inter-Am. Commission on Human Rights, Report on the Situation of Human Rights in Argentina, OEA/Ser.L/V/II.49, doc. 19 corr.1 1 A.1 (April 11, 1980), http:// www.cidh.org/countryrep/Argentina80eng/ chap.3.htm (last accessed Oct. 5, 2016).

59 See Inter-Am. Commission on Human Rights, Report on the Situation of Human Rights in Argentina, OEA/Ser.L/V/II.49, doc. 19 corr.1 (April 11, 1980), $\mid$ B B.1, http:// www.cidh.org/countryrep/Argentina80eng/ conclusions.htm (last accessed Oct. 5, 2016).
$60 \quad$ Id. at $₫$ B.7.
$61 \quad I d$. at $₫$ B.8.
62 Id. at 9 B.12.
63 Id. at $₫$ B.3. 
to not be subjected to inhumane treatment or infringements upon personal liberty or freedom of expression. The Fujimori government continued to be noncompliant with the recommendations of the Commission. ${ }^{64}$ In 1999, however, after intense negotiation with the Fujimori government, the IACHR was able to conduct on-site visits and issue a report.

The Commission employed its investigative function to highlight an array of human rights problems and requested that Peruvian authorities adopt several measures to prevent future violations. The IACHR called upon Peru to ensure respect for the principle of separation of powers, abrogate laws preventing the investigation and punishment of state agents who perpetrated human rights violations, and abrogate laws granting excessive power to the police. The Commission urged the State to align anti-terrorist legislation with the American Convention, to eradicate the practice of admitting evidence obtained under torture, to ensure the right to judicial assistance, and prohibit arbitrary arrest and torture perpetrated by the police. The IACHR strongly asked the State to make changes to its prison system, such as compensating persons who served unfair prison sentences, providing the prison system with resources, ensuring adequate conditions of detention, and eliminating solitary confinement. The Commission insisted that the State make social and administrative changes as well, such as adopting specific measures to punish attacks on investigative journalists, preventing limitations on the exercise of press freedom, guaranteeing enforcement of the minimum wage, regulating the protection of maternity, providing information on the protection of women's human rights, reintegrating children in the educational system, and strengthening the systems for the collection of data regarding the situation of children. ${ }^{65}$

\section{Third Report on the Human Rights Situation in Colombia - 1999}

The human rights situation in Colombia has been one of the main concerns of the Inter-American Commission for the past several decades. The IACHR considered that Colombia cooperated in seeking to improve the human rights situation in the country by implementing several measures recommended by the Commission in its previous (Second) Report.

\footnotetext{
64 Goldman, R., supra note 8.

65 See Inter-Am. Commission on Human Rights, supra note 56.
} 
These measures included, for instance, eliminating domestic legal barriers to victim compensation, establishing an office of the UN High Commissioner for Human Rights, ratifying international covenants and protocols related to human rights, and presenting legislation the to criminalize the forced disappearance of persons, among other things. ${ }^{66}$

However, the Third Report highlighted that violations of human rights continued to occur in a climate of political violence that included armed dissident and paramilitary groups, drug trafficking, common crime, abuse of authority, socioeconomic violence rooted in social injustice, and land disputes that led people to act criminally or threaten to destabilize the constitutional order. The Commission received numerous complaints and allegations of serious violations of fundamental rights during the period of hostility, manifested as massacres, internal displacement, executions, injuries to persons, violations of the due process rights of criminal defendants, threats, and deprivations of liberty.

Seeking to prevent further violations and improve the human rights situation in Colombia, the IACHR requested that the Government of Colombia implement several measures. Politically, the Commission urged the State to pass legislation to improve the effectiveness of social and cultural rights jeopardized by the climate of violence and forced displacement of persons; to ensure the ratification and compliance with international human rights instruments such as the Inter-American Convention on the Forced disappearance of Persons; to adopt appropriate measures for the demarcation of lands and control the exploitation of natural resources, to ensure that these measures were put into practice; and to ensure the rights and resettlement of internally displaced persons. The IACHR called upon the State to modify its treatment of minority groups: to allow indigenous populations to retain their cultural identities, values, traditions, and landscapes; to improve indigenous peoples' access to health and other public services; to ensure the physical integrity of minorities, the black community, and women; and to provide legal remedies in response to racist acts. On the judicial level, the Commission urged the State to rebuild the criminal justice system in order to enhance the role of victims in criminal procedures, to modify the conditions of imprisonment by passing legislation to build new prisons, to promote the health of prisoners and

66 See Inter-Am. Commission on Human Rights, Third Report on Democracy and Human Rights in Colombia, OEA/Ser.L/V/II.102, doc. 9 rev. 1 (26 February 1999), http:// www.cidh.org/countryrep/colom99en/introduction.htm (last accessed Oct. 5, 2016). 
programs for their rehabilitation, and to prevent prison riots and internal violence. The IACHR recommended that the State implement measures regarding women's rights, such as providing judicial staff training regarding the causes and consequences of gender-based violence, to institute measures to eradicate violence and other forms of torture and inhumane treatment towards women, to ensure women's reproductive health rights, and to promote the role of women in society. The IACHR also strongly encouraged the State to investigate the facts leading to violence against children and human rights defenders, to refrain from harassment of human rights defenders and violence against journalists and labor union members, teachers and participants in electoral politics. Lastly, the Commission called upon the State to address the problem of the inequitable distribution of wealth and increasing poverty, to improve the quality of education at all levels, to relieve the extremely difficult economic, social, and cultural situation of internally displaced persons, and to ensure the physical integrity of children affected by the internal conflict and reintegrate them into the educational system. ${ }^{67}$

\section{Report on Terrorism and Human Rights (2002)}

The IACHR released the report Terrorism and Human Rights soon after the terrorist attacks of September 11, 2001 in the United States. The main objective of the Commission in this report was to re-state the human rights standards applicable to all OAS member states when implementing counter-terrorist measures. The report was designed to provide assistance to states in facilitating the adoption of anti-terrorism measures and comply with their human rights commitments. More specifically, the Report was a response to the renewed calls in the U.S. and around the world to adopt any measures necessary to confront terrorists, many of them in evident violation of human rights law. The Commission's supervisory activities in the last few decades had been developed in the context of governments that pointed to the terrorist threat to adopt and justify measures that violated international human rights law. It was not difficult for the IACHR to recapture its own precedents and present them again in this comprehensive report. In this way the Commission sought to prevent states of the Americas from using the U.S. response to 9/11 as an excuse

67 See Inter-Am. Commission on Human Rights, supra note 10. 
to engage in practices that could reach the level of war crimes or crimes against humanity. ${ }^{68}$

As a result, the IACHR reminded States of their human rights obligations under the American Declaration, the American Convention, and other regional human rights treaties, calling on them to comply with these human rights instruments; to avoid lethal force to ensure people's protection; to restrict the use of the death penalty; to ensure compliance with minimum standards governing the right to personal liberty and security regarding persons under arrest and imprisonment; to ensure the compliance with minimum standards governing humane treatment in the context of armed conflict; to refrain from action against the publication of opinions relating to terrorism outside of armed conflicts; to ensure the protection of journalists during armed conflicts; to ensure and protect the rights of migrants, workers, asylum seekers, and refugees; to ensure equal protection under the law and distinction based on objective and reasonable standards, and to comply with the fundamental principles of due process and fair trials.

As indicated by former Commissioner Robert K. Goldman, ${ }^{69}$ these measures have been effective overall in changing the conduct of governments. Indeed, they helped Argentina to significantly decrease the number of reported disappearances, helped Colombia to implement measures that saved the lives of numerous victims, and contributed to Peru's transition to democracy after President Fujimori resigned and was prosecuted and convicted in Peruvian courts. In its Human Rights and Terrorism Report, the IACHR reiterated the human rights standards it had aimed to preserve for decades in the Americas, standards that were threatened once again after $9 / 11$. The wide array of measures requested by the Commission from states in which crimes against humanity and war crimes were occurring has served to prevent further massive human rights violations. The holistic approach that includes victim-specific measures as well as structural adjustments has served the purpose of overcoming some of the most serious situations of human rights and repairing the victims, as well as

\footnotetext{
68 See Inter-Am. Commission on Human Rights, supra note 57.

69 See for Colombia and Peru Goldman, supra note 8. See also for Argentina O. Hilaire Sobers, The Inter-American System of Human Rights, in An Institutional Approach to the Responsibility to Protect 459, 471 (Gentian Zyberi Ed., 2013).
} 
ensuring a sustainable social, political, and institutional environment that can continue to prevent the recurrence of such violations.

Country reports and in loco visits have thus been particularly effective in raising international awareness in several situations of serious violations of human rights, empowering voices and forces to exercise protection to avoid the serious crimes. For example, the visit in loco to Argentina in 1980 and the Commission Report were key in the latter domestic process of accountability for human rights violations raising standards for further protection. In general, visits and reports have allowed the Commission to interact with states at the political level in order to induce a response that protects national actors in civil wars, under authoritarian regimes, or in the context of gross and systematic violations of human rights.

\section{Conclusions}

The Inter-American Human Rights System is a set of norms and institutions that governs regional cooperation to strengthen the effective implementation of the international obligations assumed by the States vis-à-vis their populations. The Inter-American Human Rights System is subsidiary to the party first responsible for protection, which is the State in relation to the persons under its jurisdiction. In this sense, there is a similarity in the relationship between the regional human rights system and the State on the one hand and the international community and the State on the other if this State is unable to protect its population and prevent mass atrocities.

Nevertheless, the regional human rights system protects a more extensive range of rights, namely all the human rights that international instruments call for ratifying States to abide in our region, including the American Declaration and the American Convention on Human Rights. When we talk about "Responsibility to Protect", this refers to four crimes: genocide, war crimes, ethnic cleansing, and crimes against humanity. It is precisely the relationship between human rights violations and mass atrocities, however, that makes the Inter-American Human Rights System a preventive mechanism in relation to mass atrocities. To the extent that the regional community is in action through its proper mechanisms to call out and sanction human rights violations, it prevents the commission of the most serious crimes that would otherwise take place in an environment lacking protection and experiencing insecurity related to generalized human rights violations. If the system calls attention to all human rights 
violations, it should be able to give clear signs that allow regional actors to avoid the most serious crimes.

As we have shown, supervision in the Inter-American Human Rights System is the responsibility of two institutions independent from State governments: one political-judicial (the IACHR), and one purely judicial (the Court). Both the Court and IACHR have strong legitimacy, although certain governments have tried to limit their powers. The Commission opens the door to the Court to any person affected, to their families, or even to third parties requesting the IACHR to act, when a case is not settled and the State is party to the American Convention. In any case, the IACHR supervises all OAS states under the American Declaration.

The individual case system has become a strong mechanism to protect communities from systematic violations of human rights, calling attention to human rights violations suffered by individualized persons, and determining reparations when human rights violations have been demonstrated. The organs of the Inter-American Human Rights system have established severe restrictions on the legitimacy of amnesty laws in the case of crimes against humanity or war crimes, strengthening the responsibility of States to protect their populations from such crimes. Moreover, precautionary and provisional measures adopted by the Commission and the Court are an important mechanism to prevent crimes in a region that has witnessed serious human rights violations, as we have shown.

In many cases, the on-site visits of the IACHR, the visits in loco, have been crucial to highlight situations in different countries, particularly when dictatorships were in place, allowing access of the offended to the Commission, providing a space for dialogue between Commissioners and national authorities, and raising awareness of human rights violations among the regional and international community.

Reports prepared by the IACHR, especially after visits in loco, have been sent to the General Assembly of the Organization of the American States. The release of these reports had an immediate effect on the regional and international awareness of these situations. In this sense, they have also had a preventive effect to the extent they raised awareness of human rights violations and difficult situations. However, the General Assembly and other political organs of the OAS have not discussed these reports extensively, nor have they adopted specific measures to increase the efficiency of the Inter-American Human Rights system. Nevertheless, we have to take into account that IACHR reports have increased concern within the regional system regarding some situations and have been an 
important element in regional reactions, for example in the Peruvian case in 1999-2000. Furthermore, other reports such as the case of Argentina, were starting points to establish responsibilities for human rights violations after democratic transitions took place. The effect of these reports is of real concern to some governments in countries where human rights violations are denounced, as evidenced by attempts to restrict their scope and their consideration by political organs in the last process of reform of the Inter-American Human Rights system.

One very important contribution of the Inter-American Human Rights system has been the notion of "enforced disappearance of persons" now recognized in international treaties in the UN and the OAS, and defined in article 7(1)(i) and (2) (i) of the Rome Statute of the International Criminal Court as crime against humanity. ${ }^{70}$

In sum, it is clear that the Inter-American Human Rights system has a very strong component of prevention in the line of the responsibility to protect. It also has a regional system for political and judicial reaction that should help in avoiding situations that may lead to the commission of genocide, war crimes, ethnic cleansing, and crimes against humanity. However, it does not have a mechanism to put in motion the collective use of force as a response to mass atrocities.

\section{References}

\section{Books, book chapters, journal articles, and websites}

Burbano-Herrera, C. \& Rodriguez-Pinzon, D., "Precautionary Measures Issued by the Inter-American Commission on Human Rights", in Preventing Violations of Human Rights: Are Urgent, Interim or Provisional Measures an Adequate Tool in Human Rights Litigation? Haeck, Y. \& Burbano-Herrera, C., Eds., 2015.

Goldman, R., History and Action: The Inter-American Human Rights System and the Role of the Inter-American Commission on Human Rights, 31 Hum. RTS. Q. 856 (2009).

LACHR. Welcomes Order to Close Guantanamo Detention Center, Inter-Am. Comm'n on Human Rights (Jan. 27, 2009), www.cidh.oas.org/Comunicados/ English/2009/02-09eng.htm (last visited Oct. 5, 2016).

70 Rome Statute of the International Criminal Court, art. 7(1)(i) and (2)(i), supra note 10. 
Lyons, G. M. \& Mastanduno, M. (Eds.), Beyond Westphalia? State Sovereignty and International Intervention. 1995.

Muñoz, H., La responsabilidad de proteger: trespilares y cuatro crímenes, 10 Foreign Aff. Latinoamérica at 101 (2010).

Paramilitaries' Heirs: The New Face of Violence in Colombia, Human Rights Watch (Feb. 3, 2010), www.hrw.org/node/88060 (last visited Oct. 5, 2016).

Rodriguez-Pinzon, D. \& Martin, C., "The Inter-American Human Rights System: Selected Examples of its Supervisory Work", in Research Handbook on International Human Rights Law (Joseph, S. A. McBeth Eds, 2010).

Rodriguez-Pinzon, D., "Precautionary Measures of the Inter-American Commission on Human Rights: Legal Status and Importance”, 20 Hum. Rts. Brief, 2013.

Rodriguez-Pinzon, D., "Selected Examples of the Contemporary Practice of the Inter-American System in Confronting Grave Violations of Human Rights: United States and Colombia", in Making Peoples Heard: Essays on Human Rights in Honour of Gudmundur Alfredsson 371 (Asbjorn Eide et al. Eds., 2011).

Rodriguez-Pinzon, D., "The Inter-American Human Rights System and Transitional Processes", in Transitional Jurisprudence and the European Convention on Human Rights: Justice, Politics and Rights 239 (Antoine Buyse \& Michael Hamilton Eds., 2011).

Sobers, O. Hilaire, "The Inter-American System of Human Rights", in An Institutional Approach to the Responsibility to Protect 459 (Gentian Zyberi Ed., 2013).

Tittemore, B. D., "Ending Impunity in the Americas: The Role of the Inter-American Human Rights System in Advancing Accountability for Serious Crimes Under International Law", 12 S. W. J. L. \& Trade Am. 429 (2006).

What is the LACHR?, Inter-Am. Commission on Hum. Rts., http://www. oas.org/en/iachr/ mandate/what.asp (last visited Oct. 5, 2016).

\section{Reports and resolutions}

GA Res. 60/1 (Oct. 24, 2005).

Inter-Am. Comm'n on Human Rights, Address by the Chairman of the Inter-American Commission on Human Rights Paolo Carozza 
(April 3, 2008), http:/ /www.cidh.org/Discursos/ 04.03.08eng.htm (last visited Oct. 5, 2016).

Inter-Am. Comm'n on Human Rights, Annual Report of the IACHR 2006, Chapter III, www.cidh.org/ annualrep/2006eng/Chap.3c.htm (last visited Oct. 5, 2016).

Inter-Am. Comm'n on Human Rights, IACHR Annual Report 2008, Chapter III - The Petition and Case System (Continuation), www.cidh.org/ annualrep/2008eng/Chap3.e.eng.htm (last visited Oct. 5, 2016).

Inter-Am. Comm'n on Human Rights, Pertinent Parts of July 29, 2004 Reiteration and Further Amplification of Precautionary Measures (Detainees in Guantanamo Bay, Cuba), 45 I.L.M. 671 (2006).

Inter-Am. Comm'n on Human Rights, Precautionary Measures 2002, www.cidh.org/ medidas/2002.eng.htm (last visited Oct. 5, 2016).

Inter-Am. Comm'n on Human Rights, Report on Terrorism and Human Rights, OEA/Ser.L/V/II.116, doc. 5 rev. 1 corr. (Oct. 22, 2002), http:// www.cidh.org/Terrorism/ Eng/toc.htm (last visited Oct. 5, 2016).

Inter-Am. Comm'n on Human Rights, Report on the Situation of Human Rights in Argentina, OEA/Ser.L/V/II.49, doc. 19 corr.1 (April 11, 1980), http://www.cidh.org/countryrep/ Argentina80eng/toc.htm (last visited Oct. 5, 2016).

Inter-Am. Comm'n on Human Rights, Res. No. 2/06, On Guantanamo Bay Precautionary Measures (July 28, 2006), https://www.cidh. oas.org/annualrep/2006eng/ANNEXES/Annex\%205eng.htm (last visited Oct. 5, 2016).

Inter-Am. Comm'n on Human Rights, Res. No. 2/11 Regarding the Situation of the Detainees at Guantanamo Bay, United States, MC 259-02 (July 22, 2011), http://www.cidh.oas.org/pdf\%20files/ Resolution\%202-11\%20Guantanamo.pdf

Inter-Am. Comm'n on Human Rights, Second Report on the Situation of Human Rights in Peru, OEA/Ser.L/V/II.106, doc. 59 rev. June 2, 2000), http://www.cidh.org/countryrep/ Peru2000en/TOC.htm (last visited Oct. 5, 2016).

Inter-Am. Comm'n on Human Rights, Third Report on Democracy and Human Rights in Colombia, OEA/Ser.L/V/II.102, doc. 9 rev. 1 (Feb. 26, 1999), http://www.cidh.org/countryrep/ colom99en/table\%20 of $\% 20$ contents.htm (last visited Oct. 5, 2016).

Rep. of the Sec'y Gen.'s High-level Panel on Threats, Challenges and Change, A more secure world: our shared responsibility, Un Doc. A/59/565 (2004). 
un Secretary General, In Larger Freedom: Towards Security, Development and Human Rights for All, UN Doc. A/59/2005 (March 21, 2005).

\section{Jurisprudence}

19 Tradesmen v. Colombia, Merits, Reparations and Costs, Judgement, Inter-Am. Ct. HR (ser. C) No. 109 (July 5, 2004).

Barrios Altos v. Peru, Merits, Judgement, Inter-Am. Ct. HR (ser. C) No. 75 (March 16, 2001).

Gelman v. Uruguay, Merits and Reparations, Judgement, Inter-Am. Ct. HR (ser. C) No. 221 (Feb. 24, 2011).

Gomes Lund et al. (“Guerrilha do Araguaia”) v. Brazil, Preliminary Objections, Merits, Reparations and Costs, Judgement, Inter-Am. Ct. HR (ser. C) No. 219 (Nov. 24, 2010).

Héctor Marcial Garay Hermosilla v. Chile, Case 10.843, Inter-Am. Comm'n HR, Report No. 36/96, OEA/Ser.L/V/II.95 Doc. 7 rev. 156 (1997).

Herrera v. Argentina, Cases 10.147, 10.181, 10.240, 10.262, 10.309 and 10.311, Inter-Am. Comm'n HR, Report No. 28/92, OEA/Ser.L/V/ II.83, doc. 14 (1993).

Hugo Leonardo de los Santos Mendoza v. Uruguay, Cases 10.029, 10.036, $10.145,10.305,10.372,10.373,10.374$ and 10.375, Inter-Am. Comm'n HR, Report No. 29/92, OEA/Ser.L/V/II.83, doc. 14 (1993).

Ignacio Ellacuría, S.J. et. al. v. El Salvador, Case 10.488, Inter-Am. Comm'n HR, Report No. 136/99, OEA/Ser.L/V/II.106, doc. 6 (1999).

Ituango Massacres v. Colombia, Preliminary Objection, Merits, Reparations and Costs, Judgement, Inter-Am. Ct. HR (ser. C) No. 148 (July 1, 2006).

Las Hojas Massacre v. El Salvador, Case 10.147, Inter-Am. Comm'n HR, Report No. 26/92, OEA/Ser.L/V/II.83, doc. 14 (1993).

Las Palmeras v. Colombia, Merits, Judgment, Inter-Am. Ct. HR (ser. C) No. 90 (Dec. 6, 2001).

Mapiripán Massacre v. Colombia, Preliminary Objections, Inter-Am. Ct. HR (ser. C) No. 122 (March 17, 2005).

Massacre "Los Uvos" v. Colombia, Case 11.020, Inter-Am. Comm'n HR, Report No. 35/00, OEA/Ser.L/V/II.106, doc. 3 rev. ๆ 24 (1999).

Massacres of El Mozote and nearby places v. El Salvador, Interpretation of the Judgment on Merits, Reparations and Costs, Inter-Am. Ct. HR (ser. C) No. 264 (Aug. 19, 2013). 
Monseñor Oscar Romero v. El Salvador, Case 11.481, Inter-Am. Comm'n HR, Report No. 37/00, OEA/Ser.L/V/II.106, doc. 3 rev. \ 671 (1999).

Pueblo Bello Massacre v. Colombia, Interpretation of the Judgement, Inter-Am. Ct. HR (ser. C) No. 159 (Nov. 25, 2006).

Rochela Massacre v. Colombia, Merits, Reparations and Costs, Judgement, Inter-Am. Ct. HR (ser. C) No. 163, \ 190-198 (May 11, 2007).

Velásquez Rodríguez v. Honduras, Merits, Judgment, Inter-Am. Ct. HR (ser. C) No. 4 (July 29, 1988). 